\title{
Studies on the oesophageal groove reflex in sheep and on the potential use of the groove to prevent the fermentation of food in the rumen
}

\author{
By E. R. ØRSKOV AND D. BENZIE \\ Rowett Research Institute, Bucksburn, Aberdeen, AB2 ${ }_{9} S B$
}

(Received 8 November I968-Accepted I3 Fanuary 1969)

\begin{abstract}
I. Fluids were given by mouth in various ways to young sheep. The extent to which closure of the oesophageal groove operated to direct the fluid to the abomasum was assessed by radiography.

2. Salt solutions and milk given as a drench did not produce complete closure of the groove. However, when the animals were accustomed to sucking from a teat before weaning, any liquid suspension and also water, sucked from a bottle, passed entirely to the abomasum even in r2-month-old sheep.

3. This technique may be useful when it is desirable to cause protein or other nutrients to by-pass fermentation in the rumen.
\end{abstract}

During an experiment carried out to determine the protein requirement of early weaned lambs given concentrate diets, growth rates increased in response to increasing the concentration of protein in the diet (Ørskov \& Andrews, I968). The efficiency of protein utilization, calculated from the protein in the diet and the protein retained in the body, was, however, very low, in the region of $30 \%$. We suspected that this low efficiency was due to extensive bacterial degradation of dietary protein without an equivalent increase in the synthesis of microbial protein. Hogan \& Weston (I967) showed that the amount of microbial protein formed was related to the organic matter fermented, so that increase in the protein content of the diet may lead to little increase in protein passing to the intestines. Ørskov, Flatt \& Moe (I968) have calculated that the energy for microbial growth during anaerobiosis is directly related to the amount of carbohydrate fermented. Chalmers \& Synge (1954) suggested that dietary proteins could be protected from microbial attack in the rumen, and so pass to the intestines in greater amounts, if they were rendered less soluble, through formalin treatment, a procedure recently explored in Australia (Ferguson, Hemsley \& Reis, 1967).

This led us to investigate the possible use of the oesophageal groove reflex as a means of by-passing fermentation in the reticulo-rumen; this would ensure that a greater quantity of protein became available to the animal. This would be beneficial to animals whose protein requirement exceeded the amount which remained available after fermentation of the diet in the rumen, as might occur with young, fast-growing animals.

Such a procedure has been suggested before. Mönnig \& Quinn (1933, 1935), for instance, suggested the use of drugs to stimulate closure of the oesophageal groove. Wester (1930), in experiments with calves designed to find solutions which would stimulate closure of the groove, reported that solutions containing sodium salts were 
most successful. Watson \& Jarret (r94I) found that copper sulphate stimulated closure of the groove, although not invariably. Trautman \& Schmitt (1933) and Comline \& Titchen (195I) showed that closure of the groove was effected through a reflex mechanism dependent on receptors in the mouth and pharynx sensitive to the swallowing of certain liquids. Wise \& Anderson (1939) found that milk always stimulated closure of the groove in calves if they were allowed to suck from a pail fitted with a nipple; it was not always so when they drank from a pail.

The experiments reported here were designed to study how a liquid suspension of protein could wholly and predictably be directed to the abomasum by way of the oesophageal groove.

\section{EXPERIMENTAL}

\section{Radiography}

The course taken by liquids in the alimentary tract was studied by the addition of $10 \%(\mathrm{w} / \mathrm{v})$ of barium sulphate (Damancy Micropaque) to the liquid diet, and the application of X-ray techniques. Right lateral radiographs were taken either when the animals were standing up, or when they were held on a table fitted with a Potter-Bucky diaphragm, which prevented scattered radiation from reaching the film. Additional investigations by fluoroscopy were also made while the animals were drinking the liquids in a standing position. The radiographic exposure was $50-55 \mathrm{kV}$ and $32-4{ }^{\circ}$ $\mathrm{mA}$, using screen films together with fast tungstate intensifying screens. For the fluoroscopy examinations $60 \mathrm{kV}$ and $4 \mathrm{~mA}$ were used. Four examples of radiographs are seen in Pl. I.

The radiographs obtained provided qualitative measurements of the amount of barium sulphate in the four compartments of the stomach. The score system shown in Table I was used to indicate which compartments contained barium.

\section{Procedure}

Expt $\mathrm{I}$. The object was to study whether the reaction observed by Wester (1930) would predictably cause the oesophageal groove to function in 6-month-old sheep of Border Leicester $\times$ Scottish Blackface breeding. The sheep had been weaned from their dam when about 3 months old and had been grazing until they were brought in for the experiment. Various liquid suspensions of proteins containing various concentrations of $\mathrm{NaCl}$ were used. The liquid was given as a drench; the animal was restrained by hand, and a bottle containing 0.41 . was thrust into the side of the mouth, forcing the animal to drink the contents. The various protein suspensions and concentrations of $\mathrm{NaCl}$ used are given in Table $\mathrm{I}$.

This experiment did not reveal any effect of salt upon closure of the groove, and so in subsequent experiments the effects of age and of mode of administration of the liquid were examined.

Expt 2. Four lambs of Suffolk $\times$ Dorset Horn breeding were weaned from their dams at 2-3 weeks of age and trained to suck from a bottle with a teat. A suspension of vegetable protein was given. This was Soyolk (Soya Foods Ltd, London), a commercial milk substitute containing (\%) 6.3 moisture, $4 \mathrm{I}^{\circ} \mathrm{O}$ crude protein, $19^{\circ} \mathrm{O}$ fat, $2 \cdot 0$ phos- 
pholipids, 4.5 ash, I.5 fibre, 0.2 calcium, 0.8 phosphorus, 6.0 sucrose, 3.5 stachiose, I $\circ$ raffinose, $3^{\circ} \circ$ dextrose, $4^{\circ} \circ$ pentose, $3^{\circ} \circ$ galactose and $4^{\circ} \circ$ hemicellulose. The suspension contained $15 \%$ dry matter.

The liquid foods given to sheep of different ages were: weaning to 3 months of age, Soyolk; $3-5$ months, a liquid suspension of $25 \%$ Soyolk, $25 \%$ soya-bean meal, I $5 \%$ fish meal, $15 \%$ sunflower-seed meal and $15 \%$ linseed-oil cakes; $5-8$ months, a liquid suspension of sunflower-seed meal; 8-I2 months, a liquid suspension of casein, or water. At all times the animals were given dry feed consisting of barley concentrate except for the period from 5 to 12 months in Expt 2, when the dry feed was hay. Between the ages of 2 and 5 months radiographs were taken every 14 days, and then at monthly intervals for the remainder of the period.

Table I. Expt I : effect of the type of liquid suspension, given as a douche, on the site at which $\mathrm{BaSO}_{4}$ could be found in the stomach of the sheep

\begin{tabular}{ccc}
$\begin{array}{c}\text { No. of } \\
\text { observations }\end{array}$ & \multicolumn{1}{c}{$\begin{array}{c}\text { Mean } \\
\text { of scores }\end{array}$} & $\begin{array}{c}\text { Range } \\
\text { of scores }\end{array}$ \\
2 & $2 \cdot 0$ & $1-3$ \\
6 & $2 \cdot 8$ & $1-4$ \\
6 & $3 \cdot 2$ & $1-5$ \\
2 & $2 \cdot 5$ & $2-3$ \\
4 & $3 \cdot 0$ & $2-5$ \\
2 & $3 \cdot 5$ & $2-5$
\end{tabular}

$10 \%$ albumin $+2 \% \mathrm{NaCl}$

$10 \%$ isolated soya protein

$10 \%$ isolated soya protein $+5 \% \mathrm{NaCl}$

Io \% whole dried milk

$20 \%$ Soyolk $+3 \% \mathrm{NaCl}$

$15 \%$ isolated soya protein $+10 \%$ whole dried milk

* Score: $\mathrm{I}=$ all in the reticulo-rumen; $2=$ most in the reticulo-rumen and a trace in the abomasum; 3 = equally in the reticulo-rumen and abomasum; $4=$ a trace in the reticulo-rumen but most in the abomasum and intestine; $5=$ all the marker in the abomasum and intestine.

Expt 3. The object was to investigate the effect of the method of administration of liquid feeds on the action of the oesophageal groove. The importance of the method of administration became apparent when two 4 -month-old sheep were given a water suspension of $\mathrm{BaSO}_{4}$ and in both instances the marker was found to pass immediately to the abomasum and intestine. These two animals had been trained to suck from a bottle fitted with a teat when they were weaned at 2 weeks of age.

Six 9-month-old sheep of Border Leicester $\times$ Scottish Blackface breeding were used and also the sheep from Expt 2, when they were 5 months old, together with three animals of breed and age similar to those of the sheep in Expt 2, but which had received only dry feed and had not been trained to drink from a bottle. The liquids given were: water, water containing $15 \%(\mathrm{w} / \mathrm{v})$ of the protein mixture given to the $3-5$ months old lambs in Expt 2, and cow's milk. The methods of administration were drenching from a bottle (as in Expt I), sucking from a bottle fitted with a teat by untrained animals, or sucking from a bottle fitted with a teat by animals trained to this procedure when weaned from their dam. Varying degrees of coercion were needed to make the untrained animals take milk from the teat-bottle, but the trained animals always sucked eagerly. 
RESULTS

Expt I. The results are summarized in Table I. It can be seen that neither inclusion of $\mathrm{NaCl}$ in the suspension nor administration of milk had any marked effect on the efficiency with which the oesophageal groove directed the liquid to the abomasum. Under these conditions, therefore, salt or milk did not seem to be of use in promoting closure of the groove. For the individual sheep, the mean scores for all liquids were $3 \cdot 6,3 \cdot 2,3 \cdot 0,2 \cdot 5,2 \cdot 5$ and $I_{5} 5$ respectively, suggesting some difference between animals, but with none of them could it be predicted how much liquid would pass directly to the abomasum.

Table 2. Expt 3 : effect of method of administration and type of liquid suspension on the site at which $\mathrm{BaSO}_{4}$ could be found in the stomach of the sheep

\begin{tabular}{|c|c|c|c|c|}
\hline \multirow[b]{2}{*}{$\begin{array}{l}\text { Type of } \\
\text { suspension }\end{array}$} & \multirow[b]{2}{*}{$\begin{array}{l}\text { Method of } \\
\text { administration }\end{array}$} & \multirow[b]{2}{*}{$\begin{array}{c}\text { No. of } \\
\text { observations }\end{array}$} & \multicolumn{2}{|c|}{ Site of barium } \\
\hline & & & $\begin{array}{l}\text { Mean of } \\
\text { scores }\end{array}$ & $\begin{array}{l}\text { Range } \\
\text { of scores }\end{array}$ \\
\hline \multirow{3}{*}{ Water } & Drench & 6 & $2 \cdot 5$ & $I-5$ \\
\hline & $\begin{array}{l}\text { Involuntary from teat of } \\
\text { bottle }\end{array}$ & 4 & $2 \cdot 2$ & $1-3$ \\
\hline & $\begin{array}{l}\text { Voluntary from teat of } \\
\text { bottle }\end{array}$ & 3 & $5 \cdot 0$ & 5 \\
\hline \multirow[t]{3}{*}{ Milk } & Drench & 3 & $3 \cdot 6$ & $2-5$ \\
\hline & $\begin{array}{l}\text { Involuntary from teat of } \\
\text { bottle }\end{array}$ & 2 & I.5 & $I-2$ \\
\hline & $\begin{array}{l}\text { Voluntary from teat of } \\
\text { bottle }\end{array}$ & 2 & $5^{\circ} 0$ & 5 \\
\hline \multirow{3}{*}{$\begin{array}{l}10 \% \text { liquid suspension } \\
\text { of protein concentrate }\end{array}$} & Drench & 3 & 2.0 & $I-4$ \\
\hline & $\begin{array}{l}\text { Involuntary from teat of } \\
\text { bottle }\end{array}$ & 2 & $1 \cdot 0$ & $I-3$ \\
\hline & $\begin{array}{l}\text { Voluntary from teat of } \\
\text { bottle }\end{array}$ & 2 & $5 \cdot 0$ & 5 \\
\hline
\end{tabular}

Score: $\mathbf{I}=$ all in the reticulo-rumen; $2=$ most in the reticulo-rumen and a trace in the abomasum; $3=$ equally in the reticulo-rumen and abomasum; $4=$ a trace in the reticulo-rumen but most in the abomasum and intestine; $5=$ all the marker in the abomasum and intestine.

Expt 2. The results of this experiment showed that from birth to maturity any substance given in liquid form and sucked from a teat-bottle was found entirely in the abomasum and small intestine in every instance. The efficiency with which the oesophageal groove closed evidently did not decline with age. The animals did not seem to differentiate between the suspensions provided they were given in this way. In all of the fifty-two tests made, the liquid was directed to the abomasum and small intestine.

Expt 3. The results are given in Table 2. This experiment was designed to assess the importance of sucking from a teat as a necessary stimulus to closure. The results show clearly that the method of administration, and the animals' voluntary response to it, determined the site at which the liquid could be found in the stomach of the sheep; they also showed that when any of the liquids were given and taken voluntarily, the groove would close. All the trained animals became very excited when offered the teat-bottle; they sucked eagerly and needed no restraint. 


\section{DISCUSSION}

These results give information on an intriguing aspect of the digestive physiology of ruminants. They show that effective closure of the oesophageal groove in conscious animals is not produced by the chemical and physical stimuli associated with swallowing fluids. To achieve this, the animal must have been accustomed to sucking fluid from a teat. It is not clear whether the teat forms a necessary part of the stimulus or is required to restrict the rate of drinking, or whether it could be dispensed with. It was not possible to demonstrate an effect of teat feeding per se since the use of a teat with untrained animals gave similar results to drenching. The closure seemed to be independent of the type of liquid suspension and occurred equally well when water alone was given.

If the sodium compounds, as observed by Wester (1930), stimulated groove function in the experiments here, then the action was either retarded or inefficient so that in most instances the greater part of the drench went to the reticulo-rumen. Schalk \& Amadon (1928) directly observed the oesophageal groove of calves by looking through a rumen fistula and noted that when the calves were drinking milk from a pail the large quantities taken with each swallow forced open the groove so that much of the milk spilled over into the reticulo-rumen. It is unlikely, however, that this would explain the differences noted here between drenching and sucking from a teat-bottle since the liquid was consumed at a much greater rate when it was sucked voluntarily than when it was given as a drench.

It seems that either the act of sucking or a condition of the animals was responsible for the complete predictability of response when the animals voluntarily sucked the liquid from a teat. Comline \& Titchen (195I), in decerebrate animals, showed that muscular contractions in the groove were stimulated through receptors in the mouth and pharynx. If this stimulus is required then the receptors would be stimulated only when the liquid was sucked, and the chemical nature of the liquid would have little or no effect. It is most likely that both the stimulus and the conditioning of the animals are required to ensure an efficient functioning of the groove. In searching through the literature for evidence of an effect of animal behaviour we found that Watson (1944) in a very thorough investigation on the function of the oesophageal groove concluded 'The passage to the abomasum of liquids sucked by lambs is not determined by the temperature or the composition of the liquids, by the posture assumed by the animals while sucking, nor by the act of sucking itself. It is the result of the activation of the pattern of behaviour which surrounds the act of sucking. Either functional activity of the oesophageal groove mechanism or increased excitability of the mucous membrane of the mouth or the pharynx or both, or increased excitability of centres of the brain to afferent impulses from the mucous membrane of the mouth or the pharynx or both, forms a constituent feature of this pattern of behaviour in the same manner as wagging of the lamb's tail and bunting of its head.' While we have not examined all the factors studied by Watson our results are in complete agreement with his conclusion. In his study Watson used water and milk, but it is not surprising that the proteins suspended in water, used by us, would act in a similar manner. 
Much attention has recently been given to coating high-quality protein for ruminants with various compounds so as to avoid its degradation in the rumen. The findings here show that degradation might be prevented by stimulating closure of the oesophageal groove. This would be of importance during periods of high protein requirement, for example when the protein needed is greater than the maximum rate of microbial production of protein. Such a situation may occur particularly in young fast-growing ruminants and high-yielding lactating ruminants.

Recent observations from this Institute (E. R. Ørskov, M. Kay, \& D. Benzie, unpublished) have shown that, with young calves, the act of sucking liquid suspensions of fishmeal from a teat leads, with trained animals, to closure of the groove. One disadvantage of this method is that it necessitates training in the use of the teat.

During periods when high intakes of specific nutrients are not needed, the pattern of behaviour associated with sucking from a teat-bottle can be maintained by giving the animals water to drink in this way.

It is possible that bottle feeding with liquids may have an adverse effect on the intake of dry feed. This possibility is at present being investigated, together with a study of effects on nitrogen retention of protein supplements and amino acids administered in this way.

The authors express their appreciation to $\mathrm{Mr}$ G. Wenham for his technical assistance and to Dr R. N. B. Kay for constructive comments and criticisms in reading the typescript.

\section{REFERENCES}

Chalmers, M. I. \& Synge, R. L. M. (1954). F. agric. Sci., Camb. 44, 263.

Comline, R. S. \& Titchen, D. A. (1951). F. Physiol., Lond. 115, 210.

Ferguson, K. A., Hemsley, J. A. \& Reis, P. J. (1967). Aust. F. Sci. 30, 2 I 5.

Hogan, J. P. \& Weston, R. H. (1967). Aust. F. agric. Res. 18, 973.

Mönnig, H. O. \& Quinn, J. I. (1933). Onderstepoort F. vet. Sci. Anim. Ind. I, I I7.

Mönnig, H. O. \& Quinn, J. I. (1935). Onderstepoort Y. vet. Sci. Anim. Ind. 5, 483 .

Ørskov, E. R. \& Andrews, R. P. (1968). Anim. Prod. 1o, 243.

Ørskov, E. R., Flatt, W. P. \& Moe, P. W. (I968). F. Dairy Sci. 51, I429.

Schalk, A. F. \& Amadon, R. S. (1928). Bull. N. Dak. agric. Exp. Stn no. 2 I6.

Trautmann, A. \& Schmitt, J. (1933). Arch. Tierernähr. Tierz. 9, I.

Watson, R. H. (1944). Bull. Commonw. Coun. scient. ind. Res. no, 180, p. I.

Watson, R. H. \& Jarrett, J. G. (1941). Aust. vet. F. 17, 137.

Wester, I. (1930). Berl. tierärztl. Wschr. 46, I.

Wise, G. H. \& Anderson, G. W. (1939). 7. Dairy Sci. 22, 697.

\section{EXPLANATION OF PLATE}

Barium sulphate was given to sheep in liquid protein suspension as a drench. In $(A)$ it was present in the reticulum and rumen with faint traces in the omasum, and in $(B)$ it was present in the reticulum and rumen with traces in the omasum and abomasum. After a trained animal had sucked barium sulphate mixed with liquid protein suspension from a teat-bottle the marker passed directly to the abomasum, there being none detectable in the rumen or reticulum $(C)$. Vigorous contraction of the pylorus can be seen in $(C)$. After administration for $5 \mathrm{~min}$ by sucking from a teat-bottle the barium began to pass to the intestines $(D)$. These radiographs were taken with the animals held on their right sides on a table. 
British Yournal of Nutrition, Vol. 23, No. 2

Plate I
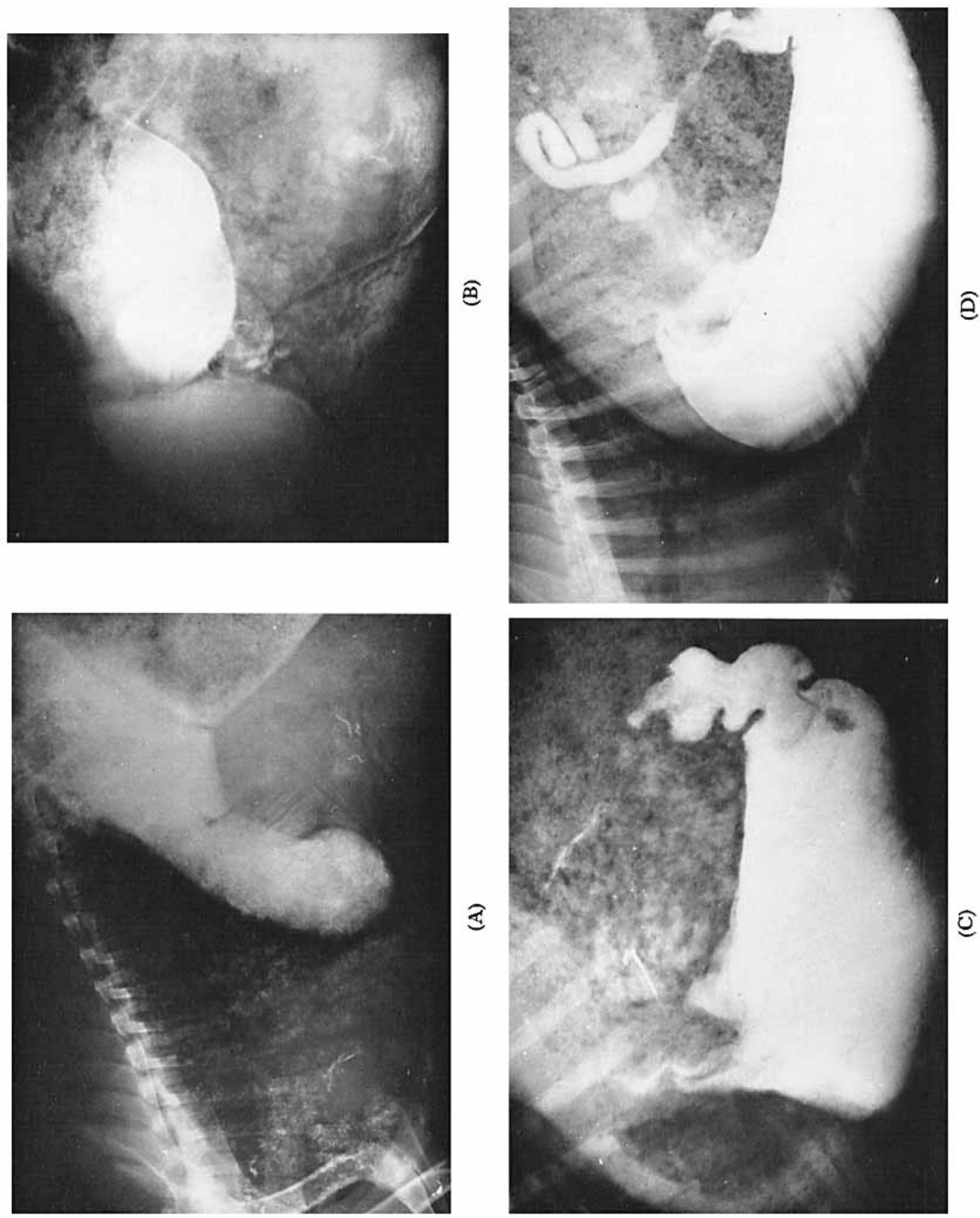

E. R. ØRSKOV AND D. BENZIE

(Facing p. 420) 